P-ISSN 2442-6636

E-ISSN 2355-3987

www.ijhn.ub.ac.id

Artikel Hasil Penelitian

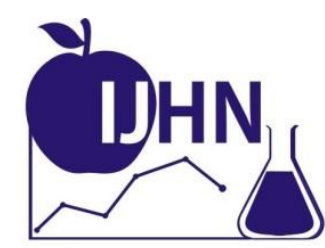

\title{
Asupan Vitamin C dan E Tidak Mempengaruhi Kadar Gula Darah Puasa Pasien DM Tipe 2
}

\author{
Cleonara Yanuar Dini ${ }^{{ }^{*}}$, Maulida Sabila ${ }^{1}$, Intan Yusuf Habibie ${ }^{1}$, Fajar Ari Nugroho ${ }^{1}$ \\ Jurusan Gizi Fakultas Kedokteran Universitas Brawijaya Malang \\ *Alamat korespondensi: cleonarayd@ @mail.com Tlp : +628113666037
}

Diterima: September 2017

Direview: Oktober 2017

Dimuat: Desember 2017

\begin{abstract}
Abstrak
Prevalensi diabetes melitus di Jawa Timur menempati urutan ke-5 teratas Indonesia. Diabetes melitus terjadi akibat resistensi insulin sehingga kadar gula darah tinggi. Kontrol glukosa darah pada pasien diabetes mellitus dapat dipengaruhi oleh asupan vitamin $\mathrm{C}$ dan $\mathrm{E}$ dengan menghambat stres oksidatif. Banyak penelitian melihat efek pemberian suplementasi kedua vitamin tersebut namun penelitian mengenai asupan makan harian sumber vitamin $C$ dan vitamin $E$ terhadap kadar glukosa darah puasa di Indonesia belum banyak dilakukan. Tujuan penelitian ini adalah mengetahui hubungan asupan vitamin $\mathrm{C}$ dan $\mathrm{E}$ terhadap kadar gula darah puasa pasien rawat jalan diabetes melitus tipe 2 di Puskesmas Dinoyo dan Janti Kota Malang. Penelitian ini merupakan penelitian cross sectional dengan jumlah responden 31 orang yang diambil secara purposive sampling. Data asupan vitamin $\mathrm{C}$ dan E selama 3 bulan terakhir dicatat menggunakan form SQFFQ. Nilai median asupan vitamin $C$ dan vitamin E seluruh responden berturut-turut adalah 95,1 $\mathrm{mg}$ dan 5,3 mg. Median kadar glukosa darah puasa seluruh responden adalah $191 \mathrm{mg} / \mathrm{dL}$. Uji analisa hubungan vitamin $\mathrm{C}$ dan $\mathrm{E}$ dengan kadar gula darah menggunakan uji Pearson (CI 95\%) menunjukkan nilai hubungan asupan vitamin $\mathrm{C}$ dan $\mathrm{E}$ terhadap kadar gula darah berturut-turut $\mathrm{p}=$ 0.697 dan $p=0.215$. Disimpulkan bahwa tidak ada hubungan antara asupan vitamin $C$ dan vitamin E terhadap kadar gula darah pasien rawat jalan DM tipe 2 di Puskesmas Dinoyo dan Janti Kota Malang.
\end{abstract}

Kata kunci: Diabetes Melitus Tipe 2, Gula Darah Puasa, Asupan Vitamin C, Asupan Vitamin E

\begin{abstract}
The prevalence of diabetes mellitus in East Java is ranked 5th in Indonesia. Diabetes mellitus occurs due to insulin resistance that results in high blood glucose level. Blood glucose control in diabetes mellitus patients can be affected by vitamin $C$ and $E$ intake through inhibiting oxidative stress. Many research have studied the effects of both vitamins supplementation but research on daily intake of vitamin $C$ and vitamin E sources on fasting blood glucose level in Indonesia have not been widely conducted. This research aims to determine the effect of vitamin $C$ and $E$ intake on fasting blood sugar level of diabetes mellitus type 2 patients in Dinoyo and Janti Health Center Malang. This research was cross sectional research with 31 respondents taken by purposive sampling. Data on vitamin $C$ and $E$ intake during the last 3 months were documented using $S Q$ FFQ form. The mean values of vitamin C and vitamin $E$ intake of all respondents were $95.1 \mathrm{mg}$ and $5.3 \mathrm{mg}$, respectively. The mean fasting blood glucose level of all respondents was $191 \mathrm{mg} / \mathrm{dL}$. Test analysis of vitamin $C$ and E relationship with blood sugar level using Pearson test $(95 \%$ CI)
\end{abstract}


showed the value of vitamin $C$ and $E$ intake relation to blood sugar level were $p=0.697$ and $p=$ 0.215 , respectively. It is concluded that there is no correlation between intake of vitamin $C$ and vitamin E on blood glucose level of DM type 2 patient in Dinoyo and Janti Health Center Malang.

Keywords: Type 2 Diabetes Mellitus, Fasting Blood Glucose, Vitamin C intake, Vitamin E intake

\section{PENDAHULUAN}

Diabetes Melitus Tipe-2 (DMT-2) merupakan penyakit dengan angka kesakitan, kematian, dan kecacatan yang tinggi di seluruh dunia. Jumlah penderita DMT-2 pada tahun 2000 adalah 171 juta orang dan diperkirakan mengalami peningkatan sampai 366 juta orang pada tahun 2030 [1]. Prevalensi penduduk Indonesia yang didiagnosa menderita DMT-2 mengalami peningkatan pada tahun 2013 yaitu sebesar $2,1 \%$, jumlah ini lebih tinggi dibanding tahun 2007 yaitu sebesar 1,1\% [2]. Provinsi Jawa Timur pada tahun 2013 menempati prevalensi DM urutan ke-5 teratas di Indonesia yaitu sebesar $2,1 \%$. Sedangkan prevalensi DM di Kota Malang menempati urutan ke-11 tertinggi dari 38 kota dan kabupaten se-Jatim yaitu sebesar 2,3\% [2].

Berdasarkan data dari Dinas Kesehatan Kota Malang tahun 2014, jumlah pasien DM tipe 2 rawat jalan tertinggi terdapat di Puskesmas Dinoyo dan Janti. Pada pasien rawat jalan DM, asupan makan dan vitamin serta glukosa darah kurang terkontrol dibandingkan pada pasien rawat inap. Pasien rawat jalan cenderung tidak memperhatikan makanan yang mereka konsumsi sehingga glukosa darah sulit terkendali sehingga kondisi hiperglikemia terus terjadi pada pasien DMT-2 rawat jalan di kedua puskesmas tersebut [7].

Pembentukan Reactive Oxygen Species (ROS) merupakan dampak dari kondisi hiperglikemia kronis akibat adanya gangguan respon reseptor insulin pada membran sel. Pada penderita DMT-2 peningkatan pembentukan radikal bebas dapat meningkatkan stress oksidatif dan menyebabkan peningkatan resistensi insulin sehingga kontrol terhadap gula darah semakin memburuk [3]. Antioksidan dari luar terutama bersumber dari makanan diperlukan untuk menanggulangi masalah ini sehingga dapat meningkatkan kualitas hidup penderita DMT-2. Sumber antioksidan yang berkaitan dengan perbaikan profil gula darah adalah vitamin $\mathrm{C}$ dan vitamin E [1].

Vitamin C diketahui dapat menghambat penumpukan sorbitol yang diakibatkan oleh kondisi hiperglikemia melalui jalur poliol-sorbitol. Dalam jalur ini vitamin $C$ berperan sebagai inhibitor enzim aldolase reductase yang mengubah glukosa dalam sel menjadi sorbitol sehingga dapat mencegah penumpukan sorbitol dan menurunkan stress oksidatif serta perbaikan fungsi endothelial Vitamin $\mathrm{C}$ juga berperan dalam memodulasi aksi insulin pada penderita DM dan berhubungan dengan menurunkan kadar glukosa darah [4]. Vitamin E berfungsi sebagai kofaktor enzim glutation peroksidase (GPX) dalam meningkatkan level glutation di dalam darah yang mempunyai kemampuan sebagai antioksidan. Vitamin E diketahui dapat menurunkan glukosa darah melalui penurunan stress oksidatif [6].

Beberapa penelitian terdahulu menunjukkan konsentrasi vitamin $\mathrm{C}$ atau vitamin $\mathrm{E}$ plasma berhubungan negatif dengan resiko DM tipe-2 yang disebabkan oleh peningkatan stress oksidatif. Namun konsentrasi vitamin tersebut pada penelitian ini lebih mencerminkan asupan jangka pendek sebelum penelitian tersebut dilakukan. Asupan harian vitamin $\mathrm{C}$ dan $\mathrm{E}$ dengan menggunakan form food frequency questionnaire (FFQ) lebih dapat mencerminkan asupan dalam jangka waktu lama dibandingkan dengan melihat konsentrasi vitamin $\mathrm{C}$ dan $\mathrm{E}$ dalam plasma. Dalam 3 penelitian prospektif dan 1 meta 
analisis telah diteliti hubungan antara asupan harian vitamin $\mathrm{C}$ atau vitamin $\mathrm{E}$ namun semua penelitian itu dilakukan pada populasi Eropa dan Amerika. Penelitian mengenai pengaruh asupan harian vitamin $\mathrm{C}$ dan vitamin $\mathrm{E}$ terhadap pasien DMT-2 juga telah dilakukan di Cina yang mewakili wilayah Asia. Penelitian mengenai asupan harian vitamin $\mathrm{C}$ dan vitamin $\mathrm{E}$ yang berasal dari bahan makanan di Indonesia belum banyak dilakukan. Penelitian yang telah dilakukan terkait vitamin C dan E pada pasien DMT-2 adalah dengan pemberian suplemen seperti penelitian yang dilakukan oleh Ardekani (2007) yang membuktikan bahwa asupan $500 \mathrm{mg}$ suplementasi vitamin C selama 3 bulan dapat menurunkan kadar gula darah puasa secara signifikan. Penelitian yang dilakukan oleh Rafighi et al (2013) mengenai suplementasi vitamin $\mathrm{E}$ sebesar 900 IU perhari selama 3 bulan pada 44 responden menunjukkan hasil penurunan yang signifikan pada glukosa darah puasa responden.

Tujuan dari penelitian ini adalah untuk mengetahui hubungan asupan bahan makanan sumber vitamin $\mathrm{C}$ dan $\mathrm{E}$ terhadap kadar glukosa darah puasa pada pasien rawat jalan yang menderita DMT-2 di Puskesmas Janti dan Dinoyo Kota Malang.

\section{METODE PENELITIAN \\ Rancangan/Desain Penelitian}

Penelitian ini merupakan penelitian analitik kuantitatif dengan rancangan cross sectional.

\section{Sumber Data}

Data yang digunakan dalam penelitian merupakan data primer yang diperoleh melalui beberapa metode. Data karakteristik responden meliputi nama, jenis kelamin, alamat, tempat tanggal lahir, usia pendidikan, pekerjaan, obat dan suplemen yang dikonsumsi, responden yang hamil dan menyusui, lamanya menderita DM, sudah pernah mendapat edu- kasi atau belum didapatkan dari wawancara menggunakan form kuesioner data umum.

Data berat badan, tinggi badan, lingkar perut diperoleh melalui pengukuran langsung kepada responden untuk mendapatkan data Indeks Massa Tubuh (IMT) dan Rasio Lingkar Pinggang Pinggul (RLPP).

Data asupan vitamin $\mathrm{C}$ dan $\mathrm{E}$ diperoleh dari hasil cara bertanya langsung kepada responden menggunakan form SQFFQ yang disusun oleh peneliti. Data asupan makronutrien yaitu energi, protein, lemak dan karbohidrat didapat dengan menggunakan form estimated food record untuk melihat kecukupan asupan makronutrien tersebut. Absorbsi vitamin $\mathrm{C}$ dan $\mathrm{E}$ dapat dipengaruhi oleh asupan makronutrien.

\section{Sasaran Penelitian}

Populasi dalam penelitian ini adalah pasien rawat jalan DM tipe 2 di Puskesmas Dinoyo dan Puskesmas Janti Kota Malang. Sampel dalam penelitian ini diambil secara non probability sampling yaitu purposive sampling sebanyak 31 responden.

\section{Pengembangan Instrumen dan Teknik Pengumpulan Data}

Instrumen yang digunakan dalam penelitian ini adalah timbangan injak dengan tingkat keakuratan $0,1 \mathrm{~kg}$ untuk melakukan penimbangan berat badan, microtoise untuk melakukan pengukuran tinggi badan, pita ukur untuk mengukur lingkar pinggang dan pinggul.

Pada penelitian ini juga menggunakan instrument lain yaitu form data umum responden, form SQ-FFQ Vitamin $\mathrm{C}$ dan $\mathrm{E}$, form food record. Form SQ FFQ yang digunakan berisi 135 jenis makanan yang biasa dimakan oleh pasien DM, yang merupakan sumber vitamin $\mathrm{C}$, vitamin $\mathrm{E}$, lemak, protein dan karbohidrat, baik makanan mentah maupun makanan olahan atau jadi. Peneliti melakukan uji coba 
kuesioner kepada 20 orang pasien DM tipe 2 dari Puskesmas Dinoyo dan Puskesmas Janti yang tidak termasuk dalam sampel penelitian sehingga ditetapkanlah 147 jenis makanan sumber vitamin $\mathrm{C}$ dan vitamin $\mathrm{E}$ termasuk zat gizi makro seperti protein nabati, protein hewani, bahan makanan sumber lemak dan karbohidrat. Sebelum menjawab kuesioner ini, peneliti meminta responden untuk mengingat dan memperkirakan seberapa sering rata-rata mereka mengkonsusmsi bahan makanan tersebut dalam kurun waktu per hari, perminggu, atau tidak pernah dalam tiga bulan terakhir. Setiap item makanan yang ditanyakan disertakan gambar untuk memberikan seberapa besar gambaran porsi yang dikonsumsi.

\section{Teknik Analisis Data}

Data karakterisik dan aktivitas fisik responden dianalisis secara deskriptif. Asupan vitamin $\mathrm{C}$ dan vitamin $\mathrm{E}$ responden dianalisis menggunakan program $\mathrm{Nu}$ trisurvey 2007 untuk mengetahui jumlah asupan kedua vitamin tersebut. Kedua variabel masing-masing diuji dengan analisis univariat yaitu uji Saphiro Wilk untuk mengidentifikasi distribusi data. Analisis bivariat yaitu uji korelasi Pearson. Correlation digunakan untuk mengetahui ada tidaknya suatu hubungan antar variabel maka dilakukan dengan dengan tingkat kemaknaan yaitu 95\%.. Nilai $\mathrm{p}<0,05$ pada analisis bivariat menunjukkan signifikansi hubungan antara kedua variabel.

Penelitian ini telah laik etik dengan mendapatkan surat keterangan kelaikan etik (ethical clearance) No. 199/EC/ KEPK/05/2017 yang dikeluarkan oleh Komisi Etik Penelitian Kesehatan Fakultas Kedokteran Universitas Brawijaya.

\section{HASIL PENELITIAN \\ Karakteristik Umum}

Karakteristik responden yaitu jenis kelamin, usia, pendidikan terakhir, pekerjaan, pernah mendapat edukasi gizi, IMT, rasio lingkar pinggang dan panggul, dan lamanya menderita DM tipe 2 dapat dilihat pada Tabel 1. Secara umum responden dalam penelitian ini didominasi oleh jenis kelamin perempuan dengan kisaran usia 51-60 tahun. Responden dalam penelitian ini mayoritas berlatar belakang pendidikan tamat SD dan sebagian besar bekerja sebagai ibu rumah tangga. Mayoritas responden telah pernah mendapatkan edukasi gizi. Responden menderita DM tipe 2 yaitu dalam kisaran 5-10 tahun. Mayoritas responden yang menderita DM berstatus gizi gemuk sekali. Dilihat dari status gizi berdasarkan rasio lingkar pinggang panggul, mayoritas responden berstatus gizi obes.

\section{Asupan Makronutrien}

Data asupan makronutrien berdasarkan jenis kelamin responden dapat dilihat dalam Tabel 2. Asupan makronutrien responden didapatkan melalui metode food record yang dilakukan 3 kali pengambilan yaitu 2 hari weekdays dan 1 hari weekend. Rata-rata asupan responden laki-laki dan perempuan untuk energi, protein, dan lemak jika dibandingkan AKG pemenuhan tersebut masih tergolong kurang.

\section{Asupan Vitamin C dan $\boldsymbol{E}$}

Asupan vitamin $\mathrm{C}$ responden dapat dilihat pada tabel 3. Asupan vitamin $\mathrm{C}$ responden memiliki nilai tengah $95,1 \mathrm{mg}$. Asupan vitamin $\mathrm{C}$ responden yang termasuk dalam kategori cukup lebih banyak dibandingkan yang kurang yaitu dengan nilai tengah 96,5mg. Berdasarkan Estimated Avarage Requirement (EAR) FAO/ WHO kecukupan vitamin C adalah 45 $\mathrm{g} /$ hari dengan batas toleransi tertinggi (Tolerable Upper Intake Levels) $1000 \mathrm{mg}$ sehingga asupan vitamin $\mathrm{C}$ responden dikatakan cukup [9].

Data asupan vitamin E dapat dilihat pada Tabel 4. Asupan vitamin E responden memiliki nilai tengah 5,3 mg yang termasuk kategori kurang. Asupan vitamin E responden yang termasuk dalam kategori kurang lebih banyak dibandingkan yang 
cukup yaitu rata-rata 4,9 mg. Berdasarkan Estimated Avarage Requirement (EAR) FAO/WHO kecukupan vitamin E adalah $8 \mathrm{mg} / \mathrm{hari}$ dengan batas toleransi tertinggi (Tolerable Upper Intake Levels) $1000 \mathrm{mg}$ sehingga asupan vitamin $\mathrm{C}$ responden dikatakan kurang.

\section{Kadar Glukosa Darah Puasa}

Dari data kadar glukosa darah puasa sebagaimana pada Tabel 5 didapatkan $100 \%$ responden memiliki kadar glukosa darah > $126 \mathrm{mg} / \mathrm{dL}$ dan termasuk kadar gula tidak terkendali .

Tabel 1. Karakteristik Umum Responden

\begin{tabular}{|c|c|c|}
\hline Karakteristik Umum & $\mathrm{n}=\mathbf{3 1}$ & $\%$ \\
\hline \multicolumn{3}{|l|}{ Jenis Kelamin } \\
\hline Laki-Laki & 3 & 9,7 \\
\hline Perempuan* & 28 & 90,3 \\
\hline \multicolumn{3}{|l|}{ Usia } \\
\hline $45-50$ & 2 & 6,5 \\
\hline $51-60 *$ & 20 & 64,5 \\
\hline $61-70$ & 9 & 29 \\
\hline \multicolumn{3}{|l|}{ Pendidikan Terakhir } \\
\hline Tidak sekolah/tidak lulus SD & 4 & 12,9 \\
\hline $\mathrm{SD}^{*}$ & 14 & 45,2 \\
\hline SMP & 5 & 16,1 \\
\hline SMA & 5 & 16,1 \\
\hline Peguruan Tinggi & 1 & 3,2 \\
\hline S2 & 2 & 6,5 \\
\hline \multicolumn{3}{|l|}{ Pekerjaan } \\
\hline Pedagang & 9 & 29 \\
\hline PNS & 2 & 6,5 \\
\hline Ibu rumah tangga* & 16 & 51,6 \\
\hline Swasta & 2 & 6,5 \\
\hline Wiraswasta & 2 & 6,5 \\
\hline \multicolumn{3}{|l|}{ Pernah Mendapat Edukasi Gizi } \\
\hline $\mathrm{Ya}^{*}$ & 20 & 64,5 \\
\hline Tidak & 11 & 35,5 \\
\hline \multicolumn{3}{|l|}{ Lamanya Menderita DM tipe 2} \\
\hline $1-5$ tahun & 12 & 38,7 \\
\hline 5-10 tahun* & 14 & 45,2 \\
\hline $11-15$ tahun & 3 & 9,7 \\
\hline$>15$ tahun & 2 & 6,5 \\
\hline \multicolumn{3}{|l|}{ IMT Kategori } \\
\hline Kurus & 1 & 3,2 \\
\hline Normal & 7 & 22,6 \\
\hline Gemuk & 8 & 25,8 \\
\hline Gemuk Sekali* & 15 & 48,4 \\
\hline \multicolumn{3}{|l|}{ Kategori Rasio Lingkar Pinggang } \\
\hline \multicolumn{3}{|l|}{ Panggul (RLPP) } \\
\hline \multicolumn{3}{|l|}{ Laki-laki } \\
\hline Normal & 1 & 3,2 \\
\hline Obesitas* & 2 & 6,5 \\
\hline
\end{tabular}




\begin{tabular}{ccc}
\hline Perempuan & 2 & 6,5 \\
Normal & 26 & 83,8 \\
Obesitas* & & \\
\hline
\end{tabular}

Tabel 2. Asupan Makronutrien

\begin{tabular}{lcccccc}
\cline { 2 - 6 } & \multicolumn{3}{c}{ Pria } & \multicolumn{3}{c}{ Wanita } \\
\cline { 2 - 7 } Energi (kkal) & Mean & AKG & Pemenuhan & Mean & AKG & Pemenuhan \\
\hline Karbohidrat (g) & 1137 & 2325 & $50 \%$ & 981 & 1900 & $52 \%$ \\
\hline Protein (g) & 160 & 349 & $46 \%$ & 137 & 285 & $48 \%$ \\
\hline Lemak (g) & 42,6 & 65 & $66 \%$ & 32 & 57 & $56 \%$ \\
\hline
\end{tabular}

Tabel 3. Asupan Vitamin C

\begin{tabular}{lcccc}
\hline & Jumlah & $\mathbf{( \% )}$ & Median(mg) & Min(mg) $\mathbf{M a x}(\mathbf{m g})$ \\
\hline Kurang $(\leq 45 \mathrm{mg})$ & 4 & 12,9 & 41,4 & $27,1 \pm 49,9$ \\
\hline Cukup $(>45 \mathrm{mg})$ & 27 & 87,1 & 96,5 & $53,3 \pm 661,4$ \\
\hline Total & 31 & 100 & 95,1 & $27,1 \pm 661,4$ \\
\hline
\end{tabular}

Tabel 4. Asupan Vitamin E

\begin{tabular}{lcccc}
\hline & Jumlah & $(\boldsymbol{\%})$ & Median(mg) & Min(mg) \pm Max $(\mathbf{m g})$ \\
\hline Kurang $(\leq 8 \mathrm{mg})$ & 27 & 87,1 & 4,9 & $1,9 \pm 9,7$ \\
\hline Cukup $(>8 \mathrm{mg})$ & 4 & 12,9 & 17,8 & $11,4 \pm 21,3$ \\
\hline Total & 31 & 100 & 5,3 & $1,9 \pm 21,3$ \\
\hline
\end{tabular}

Tabel 5. Kadar Glukosa Darah Puasa

\begin{tabular}{ccccc}
\hline GDP & Jumlah & $\%$ & $\begin{array}{c}\text { Median } \\
(\mathbf{m g} / \mathbf{d L})\end{array}$ & $\begin{array}{c}\text { Min }(\mathbf{m g} / \mathbf{d L}) \pm \text { Max } \\
(\mathbf{m g} / \mathbf{d L})\end{array}$ \\
\hline $\begin{array}{c}\text { Tidak Terkendali } \\
(\geq \mathbf{1 2 6} \mathbf{~ m g / d L})\end{array}$ & 31 & 100 & 191 & $141 \pm 388$ \\
\hline
\end{tabular}

\section{PEMBAHASAN}

\section{Karakteristik Umum Responden}

Riskesdas (2007) menyebutkan bahwa prevalensi DM lebih tinggi pada perempuan dibanding laki-laki. Pada penelitian ini, sebagian besar responden adalah wanita. Pada penelitian Nurmalasari (2013) juga menunjukkan perem-puan lebih banyak menderita DM dibandingkan laki-laki. Peningkatan resistensi insulin terjadi pada wanita yang berusia diatas 40 tahun dan mengalami premenopause, karena adanya penurunan sintesis hormon estrogen [3].

Kisaran usia responden terbesar dalam penelitian ini yaitu 51-60 tahun.
Penelitian yang dilakukan oleh Rahajeng (2010) menunjukkan bahwa kelompok umur 41-64 tahun mempunyai risiko terkena DM 3,3 lebih tinggi dibandingkan dengan umur 25-40 tahun. Hal tersebut terjadi karena peningkatan intoleransi glukosa yaitu kemampuan sel beta pankreas dalam memproduksi insulin berkurang karena adanya proses penuaan. Selain itu adanya penurunan aktivitas fisik serta pola makan yang tidak terkontrol [11]. Penurunan aktivitas fisik dan pola makan yang tidak terkontrol menyebabkan sulitnya mengendalikan gula darah pada pasien diabetes melitus. 
Mayoritas responden dalam penelitian ini berlatar belakang Pendidikan tamat SD. Hal ini sejalan dengan penelitian yang dilakukan oleh Ramadhan (2016) dan Sri Utami (2014) menunjukkan bahwa sebagian besar responden yang mengalami DM berpendidikan rendah [35]. Seseorang akan sulit menerima informasi jika pendidikannya rendah karena memiliki pengetahuan yang terbatas. Hal ini mengakibatkan pemilihan makanan kurang tepat dan tidak terkontrolnya pola makan sehingga meningkatkan DM [12].

Pada penelitian ini sebagian besar responden memiliki pekerjaan sebagai ibu rumah tangga $(51,6 \%)$. Penelitian Wandansari (2013) dan Mongisidi (2014) menunjukkan penderita DM sebagian besar bekerja sebagai ibu rumah tangga yang memiliki lebih banyak waktu bersantai dan jarang melakukan latihan fisik. Kurangnya latihan fisik, menyebabkan lemak mudah tertimbun di dalam tubuh yang menyebabkan kelebihan berat badan dan memicu munculnya diabetes [36]. Peningkatan latihan fisik mendorong peningkatan kepekaan reseptor insulin di otot. Kontraksi otot yang terjadi pada saat seseorang melakukan aktivitas fisik akan mempermudah glukosa masuk ke dalam sel sehingga menurunkan resistensi insulin yang pada akhirnya akan menurunkan glukosa darah [13].

Pada penelitian ini diketahui bahwa sebagian besar responden pernah mendapatkan gizi mengenai DM. penelitian ini di dukung oleh penelitian Faradhita dkk (2014) bahwa responden DM tipe 2 didominasi oleh yang telah mendapat edukasi. Gula darah yang masih tinggi pada responden disebabkan sebagian besar responden masih belum dapat memonitoring diri dalam kontrol gula darah dari segi diet, aktivitas fisik, dan obat [14].

Mayoritas responden dalam penelitian ini telah menderita DM tipe 2 dalam kisaran 5-10 tahun. Hal ini sejalan dengan penelitian yang dilakukan oleh Gumilang
(2014) dan Hestada (2016) menunjukkan bahwa responden yang menderita DM tipe 2 paling banyak dalam durasi 5-10 tahun. Gula darah yang tidak terkontrol dapat terjadi pada penderita diabetes mellitus yang sudah terjadi lama. Hal ini disebabkan karena ketidaksadaran pasien dan keterlambatan diagnosis karena pasien datang kepada tenaga medis saat penyakit sudah parah. Pasien dengan durasi lama menderita dilaporkan lebih sering mengkonsumsi makanan yang tidak sesuai, dengan proporsi lemak jenuh yang besar serta tidak menjalani diet dengan benar sehingga kemungkinan menyebabkan gula darah meningkat [14].

Dilihat dari status gizi, sebagian besar responden memiliki status gizi gemuk sekali. Hal ini sejalan dengan penelitian yang dilakukan oleh Syauqi (2015) dan Adnan (2013) bahwa sebagian besar responden yang menderita DM tipe 2 berstatus gizi lebih. Timbunan lemak yang berlebih pada orang dengan status gizi obesitas membuat sel tubuh tidak peka terhadap insulin dan bekerja secara tidak optimal sehingga mengakibatkan hiperglikemia. Hiperglikemia akan memicu stres oksidatif yang dapat membentuk radikal bebas baru [15].

Sedangkan status gizi berdasarkan rasio lingkar pinggang panggul, mayoritas responden berstatus gizi obesitas sebanyak 26 orang perempuan dan 2 orang laki-laki. Hal ini didukung oleh penelitian Septyaningrum dan Martini (2014) menunjukkan hasil bahwa terdapat hubungan antara RLPP dengan kadar gula darah. Sel lemak yang paling banyak menghasilkan adipositokin (zat yang dapat menyebabkan resistensi insulin) adalah yang terdapat pada abdomen. Pada orang obesitas, adipositokin jumlahnya lebih banyak dibandingkan pada orang yang tidak gemuk sehingga membuat gula darah sulit masuk ke dalam sel dan menyebabkan gula di dalam darah menjadi tinggi sehingga terjadilah diabetes [16]. 


\section{Asupan Vitamin C Responden}

Berdasarkan hasil penelitian, diketahui bahwa sebagian besar atau $87,1 \%$ responden pasien DM tipe 2 di Puskesmas Janti dan Dinoyo memiliki asupan vitamin $\mathrm{C}$ yang cukup. Hal ini sejalan dengan penelitian oleh Nurlita (2015) bahwa $98,6 \%$ responden DM di RSUD Dr.Moewardi telah memenuhi kebutuhan vitamin C. Pada penelitian tersebut asupan vitamin $\mathrm{C}$ terpenuhi karena responden banyak mengonsumsi buah dan sayur yang mengandung vitamin $\mathrm{C}$ walaupun dengan kadar yang berbeda setiap jenisnya. Pada penelitian ini berdasarkan hasil SQ FFQ yang telah dilakukan, buah dan sayur banyak berkontribusi dalam asupan vitamin C responden khususnya sayur. Hampir seluruh respoden sering mengonsumsi sayur dalam berbagai bentuk olahan. Berdasarkan rekomendasi asupan vitamin $\mathrm{C}$ untuk penderita DM dianjurkan untuk mengonsumsi vitamin $\mathrm{C}$ tidak lebih dari 1000 - $3000 \mathrm{mg}$ per hari [20].

Peran vitamin C dalam DM berfungsi sebagai antioksidan yang dapat mencegah radikal bebas. Vitamin $\mathrm{C}$ dapat menghambat enzim aldose reduktase dan produksi AGE yang berada pada jalur poliol sorbitol yang secara tidak langsung akan menghambat terjadinya stres oksidatif yang diakibatkan hiperglikemia [21]. Vitamin $\mathrm{C}$ dapat meregenerasi vitamin $\mathrm{E}$ dalam mendonorkan ion hidrogen. Mekanisme vitamin $\mathrm{C}$ dan $\mathrm{E}$ dalam menghambat radikal bebas dan stres oksidatif yaitu dimulai dengan vitamin $\mathrm{E}$ akan menangkap radikal bebas, vitamin $\mathrm{E}$ berubah menjadi vitamin $\mathrm{E}$ radikal dengan mekanisme $\alpha$-tocoferol radikal yang berubah menjadi $\alpha$-tocoferol perokside. Dari dua $\alpha$-tocoferol radikal berubah menjadi $\alpha$ tocoferol dimer dan akhirnya menjadi $\alpha$ tocoquinone. Vitamin $\mathrm{C}$ dan vitamin $\mathrm{E}$ dapat mencegah reaksi oksidasi dengan mengikat vitamin $\mathrm{E}$ radikal yang terbentuk pada proses pemutusan reaksi radikal bebas oleh vitamin $\mathrm{E}$ menjadi vitamin $\mathrm{E}$ bebas atau kembali menjadi $\alpha$ tocoferol yang berfungsi kembali sebagai antioksidan. Vitamin $\mathrm{C}$ akan mengurangi oksigen radikal dan menghambat proses oksidatif [22].

Sumber yang kaya akan vitamin C dapat diperoleh dari sayur dan buah yaitu brokoli, kubis, kecambah, kentang, jeruk, jambu biji, pepaya, mangga, buah naga, melon, strawberry, dan sumber vitamin $\mathrm{C}$ yang lain yang baik dikonsumsi untuk penderita diabetes [23].

\section{Asupan Vitamin E Responden}

Berdasarkan hasil penelitian, diketahui bahwa sebagian besar atau $87,1 \%$ responden pasien DM tipe 2 di puskesmas Janti dan Dinoyo memiliki asupan vitamin E yang kurang. Hal ini sejalan dengan penelitian oleh Sri Utami dkk (2014) menunjukkan bahwa seluruh responden DM tipe 2 di memiliki asupan vitamin E yang kurang dari kebutuhan. Penelitian tersebut menyebutkan bahwa kekurangan asupan vitamin E bisa disebabkan karena beberapa faktor yaitu usia yang sudah tua, faktor ekonomi, dan pekerjaan responden yang tidak tentu [21].

Berdasarkan hasil SQ FFQ responden dalam penelitian ini, asupan vitamin $\mathrm{E}$ rendah dikarenakan asupan vitamin $\mathrm{E}$ yang didapat dari sumber makanan belum terpenuhi karena responden jarang mengkonsumsi bahan makanan yang kaya akan vitamin E seperti kacang-kacangan, kedelai, asparagus, brokoli, margarin, dan mentega. Rata-rata responden mengonsumsi sumber vitamin $\mathrm{E}$ dalam jumlah yang sedikit. Pada orang DM tidak ditemukan dalam PERKENI, ADA, dan WHO untuk anjuran asupan vitamin E yang baku atau spesifik sehingga peneliti menghubungkan pemenuhan vitamin $\mathrm{E}$ dengan Estimated Avarage Requirement (EAR) FAO/WHO.

Vitamin E mempunyai peran dalam perbaikan transport glukosa dan sensitivas insulin. Selain itu, vitamin E dapat mem- 
perbaiki potensi sistem pertahanan radikal bebas dengan meningkatkan level glutation di dalam darah. Vitamin E berperan sebagai kofaktor enzim GPX yang membantu menetralkan radikal bebas melalui reduksi glutation [4]. Radikal bebas yang dapat dicegah akan menghambat terjadinya kerusakan sel beta agar sensitivitas dan sekresi insulin tidak terganggu. Contoh bahan makanan sumber vitamin $\mathrm{E}$ yaitu kacang-kacangan, kedelai, asparagus, brokoli, jagung, minyak biji bunga matahari, gandum, margarin, dll. Batas maksimal toleransi konsumsi vitamin $\mathrm{E}$ untuk usia 19 tahun ke atas yaitu $1000 \mathrm{mg}$ per hari atau 1500 IU [9].

\section{Kadar Gula Darah Puasa Responden}

Hasil pemeriksaan gula darah puasa pada penelitian ini menunjukkan bahwa seluruh responden memiliki kadar gula darah puasa tidak terkendali $(\geq 126$ $\mathrm{mg} / \mathrm{dl})$. Hal ini sejalan dengan penelitian Utami (2015) bahwa 96,3\% pasien DM tipe 2 di Rumah Sakit Tugurejo Semarang memiliki kadar gula darah puasa tidak terkendali. Penelitian Nurulita (2015) menunjukkan bahwa 79,2\% responden DM tipe 2 di RSUD Dr.Moewardi memiliki kadar gula darah puasa tidak terkendali.

Faktor yang mempengaruhi tidak terkendalinya gula darah beberapa diantaranya adalah pengaturan makan, olahraga, dan kepatuhan pengobatan [10]. Pengaturan makan adalah kebiasaan makan individu yang terdiri dari jenis dan frekuensi makan. Hal ini diakibatkan pengaturan makan mampu mengontrol kadar gula darah dan lemak normal. Asupan makanan dapat meningkatkan gula darah sehingga mengakibatkan gula darah setelah makan meningkat [17].

Penelitian yang dilakukan oleh Rachmawati (2010) menunjukkan hasil bahwa adanya hubungan latihan fisik terhadap kadar gula darah. Hal tersebut terjadi dikarenakan aktifitas fisik mampu menurunkan kadar gula darah. Olahraga menyebabkan peningkatan pemakaian glukosa darah oleh otot sehingga mampu menurunkan kadar lemak, gula darah yang terkontrol, dan memperbaiki sensitivitas insulin. Semakin tinggi aktifitas fisik, otot skelet mengalami stres oksidatif lebih besar dibandingkan hati atau jantung karena adanya peningkatan produksi glutation. Maka otot membutuhkan perlindungan antioksidan melawan kerusakan oksidatif yang mungkin terjadi selama dan sesudah latihan fisik [11]. Kurangnya aktifitas fisik menyebabkan kepekaan reseptor insulin di otot yang aktif mengalami penurunan. Fungsi dari vitamin $C$ dan $E$ sebagai pertahanan primer melawan pembentukan ROS menurun sehingga glukosa sulit masuk ke dalam sel dan menyebabkan resistensi insulin serta glukosa darah meningkat [13].

Faktor selanjutnya yang memengaruhi gula darah yaitu kepatuhan pemakaian obat. Pasien yang minum obat tidak teratur dan gaya hidup yang salah dan tidak sehat akan meningkatkan kadar gula darah dan memperburuk kondisi penyakitnya. Vitamin $\mathrm{C}$ mempunyai kemampuan sebagai penginduksi enzim yang bekerja pada proses metabolisme obat di dalam tubuh dimana proses tersebut menghasilkan biotransformasi dari obat ke metabolit. Metabolit bersifat lebih polar dan banyak yang diekskresikan melalui urin sehingga jumlah obat aktif di dalam saluran sistemik berkurang [18]. Kadar obat di dalam darah menjadi kecil sehingga efek dari obat metformin dan glibenklamid yang dikonsumsi responden menurun. Proses metabolisme obat menurunnya efek obat menyebabkan gula darah tetap tidak terkendali [19]. Walaupun vitamin $\mathrm{C}$ tidak spesifik berinteraksi pada obat tetapi ada kemungkinan ada reaksi yang terjadi. Namun penelitian ini tidak bisa menghubungkan secara jelas karena bukan terkait variabel yang di teliti. 


\section{Hubungan Asupan Vitamin $C$ dengan Kadar Gula Darah Puasa}

Uji statistik pada penelitian ini menunjukkan bahwa hubungan antara asupan vitamin $\mathrm{C}$ dengan kadar gula darah puasa responden adalah tidak signifikan $(\mathrm{p}>0,05)$. Hal ini didukung oleh penelitian Wulandari (2014) yang menunjukkan hasil yang tidak signifikan antara asupan vitamin $\mathrm{C}$ yang dilihat dari bahan makanan alami terhadap kadar glukosa darah responden [24]. Penelitian ini juga sejalan dengan penelitian Malazy et al (2014) bahwa konsumsi suplementasi vitamin C $500 \mathrm{mg}$ setiap hari selama 3 bulan menunjukkan hasil yang tidak signifikan antara vitamin $\mathrm{C}$ dengan kadar gula darah puasa [25]. Namun, beberapa penelitian juga menunjukkan hasil yang berlawanan dengan penelitian ini. Penelitian Ardekani et al (2007) setelah diberikan suplementasi vitamin C sebesar $1000 \mathrm{mg}$ per hari selama 6 minggu menunjukkan hasil penurunan yang signifikan pada pengukuran gula darah puasa responden [26]. Hasil penelitian ini juga berlawanan dengan penelitian yang dilakukan oleh Rafighi et al (2013) bahwa setelah diberikan suplementasi vitamin $\mathrm{C}$ sebesar $800 \mathrm{mg}$ perhari selama 3 bulan menunjukkan hasil penurunan yang signifikan pada glukosa darah puasa responden [27].

Pada penelitian yang menunjukkan signifikansi dikarenakan pada penelitian tersebut menggunakan suplementasi dengan dosis besar yaitu antara 800-1000 mg. Pada penelitian ini responden yang mengkonsumsi suplemen vitamin $\mathrm{C}$ dikeluarkan dari penelitian karena peneliti ingin mengkaji dari asupan responden saja tanpa pengaruh suplementasi. Walaupun asupan vitamin $\mathrm{C}$ sudah memenuhi kebutuhan, namun asupan responden masih lebih rendah dibandingkan penelitian yang memiliki pengaruh pada kadar gula darah. Asupan yang rendah ini bisa disebabkan adanya underreporting. Penelitian oleh
Mulyadi (2013) menyebutkan bahwa metode SQ FFQ sangat bergantung pada daya ingat, sehingga dapat mengakibatkan pelaporan jumlah asupan $\mathrm{C}$ rendah atau underreporting [28]. Kedua, kurangnya variasi makanan yang dikonsumsi oleh responden. Ketiga, menurunnya selera makan diakibatkan usia yang menua. Penelitian yang dilakukan Tamba (2014) pada lansia menunjukkan hasil bahwa ada hubungan antara kurangnya variasi menu makanan dengan selera makan yang menurun sehingga asupan makan rendah. Keempat, sebagian besar responden pada penelitian ini memiliki tingkat pendidikan yang rendah sehingga berkaitan dengan pengetahuan yang rendah dan belum mengetahui fungsi vitamin $\mathrm{C}$ terkait DM. Ketika asupan vitamin $\mathrm{C}$ rendah terjadi penghambatan secara kompetitif antara asam askorbat dan glukosa. Vitamin $\mathrm{C}$ mempunyai struktur yang hampir sama dengan glukosa yang berperan di sitosol secara ekstrasel. Jika kadar glukosa meningkat berarti lebih sedikit vitamin $\mathrm{C}$ yang masuk ke dalam sel, sehingga kelebihan yang tidak digunakan dikeluarkan melalui urin [29].

Hal yang menyebabkan konsumsi vitamin $\mathrm{C}$ sudah cukup sesuai namun gula darah tetap tidak terkendali adalah pertama vitamin $\mathrm{C}$ mudah rusak karena suhu. Namun vitamin $C$ pada pengaruh suhu tidak didapatkan data pada penelitian ini. Penelitian yang dilakukan oleh Nurulita (2015) menyebutkan bahwa pada saat proses pemanasan, kandungan vitamin $\mathrm{C}$ akan berkurang jika suhunya semakin tinggi karenanya adanya oksidasi. Vitamin C menjadi asam L-dehidroaskorbat dan berubah menjadi L-diketogulonat dimana terdapat vitamin $\mathrm{C}$ yang tidak aktif. Sebanyak apapun mengonsumsi sumber vitamin $\mathrm{C}$ namun dengan pemasakan yang salah akan mengurangi efek vitamin C sebagai antioksidan [30]. Kedua, sebagian besar responden memiliki status gizi obesitas dimana timbunan lemak berlebih 
menyebabkan sel beta kurang peka terhadap rangsangan akibatnya insulin bekerja tidak optimal dan gula darah naik [16]. Ketiga, sebagian besar responden pada penelitian ini adalah perempuan. Perempuan diketahui lebih berisiko untuk terkena DM yang disebabkan penurunan hormon estrogen memicu resistensi insulin sehingga gula darah meningkat [3]. Keempat, vitamin C memiliki kemampuan untuk menginduksi sitokrom p450 yaitu enzim yang bekerja pada proses metabolisme obat. Karena banyak metabolit yang di ekskresikan melalui urin sehingga jumlah obat aktif di dalam saluran sistemik berkurang. Hal itu menyebabkan efek obat menurun dan gula darah tetap tidak terkendali [18].

\section{Hubungan Asupan Vitamin $E$ dengan Kadar Gula Darah Puasa}

Uji statistik pada penelitian ini menunjukkan bahwa hubungan antara asupan vitamin $\mathrm{E}$ dengan kadar gula darah puasa responden adalah tidak signifikan (p>0,05). Hal ini didukung oleh Utami (2015) ditemukan hasil bahwa tidak ada hubungan yang signifikan antara asupan vitamin E dengan kadar gula darah. Penelitian Jamalan et al (2015) juga menunjukkan pemberian suplementasi vitamin E $300 \mathrm{mg}$ atau $400 \mathrm{IU}$ per hari selama 4 minggu menunjukkan hasil yang tidak signifikan antara vitamin $\mathrm{E}$ dengan kadar gula darah puasa responden [31]. Namun ada beberapa penelitian menunjukkan hasil yang berlawanan dengan penelitian ini. Penelitian oleh Rafraf et al (2012) menunjukkan hasil bahwa setelah diberikan suplementasi vitamin E sebesar $400 \mathrm{mg}$ per hari selama 8 minggu menunjukkan hasil penurunan yang signifikan pada pengukuran gula darah puasa dibandingkan dengan sebelum diberikan perlakuan [32]. Hasil penelitian ini juga tidak sejalan dengan penelitian Rafighi et al (2013) yang menunjukkan adanya signifikansi setelah pemberian suplemen- tasi vitamin E sebesar 900 IU perhari selama 3 bulan terhadap glukosa darah puasa responden [27].

Pada penelitian yang menunjukkan signifikansi dikarenakan pada penelitian tersebut menggunakan suplementasi vitamin E dengan dosis besar. Selain itu, penelitian tersebut menyebutkan bahwa pemberian kombinasi suplementasi antioksidan memiliki efek yang lebih baik dan lebih efektif dibandingkan hanya satu suplementasi. Pada penelitian Steinberg (2010) mengemukakan bahwa terapi antioksidan butuh waktu lebih dari 5 tahun untuk terjadi perubahan patologis pada pasien DM. Sedangkan pada penelitian ini hanya mengkaji dari asupan vitamin $\mathrm{E}$ yang berasal dari bahan makanan alami dan tidak ada tambahan suplementasi. Pada penelitian ini responden yang mengkonsumsi suplemen vitamin E dikeluarkan dari penelitian karena peneliti ingin mengkaji dari asupan responden saja tanpa pengaruh suplementasi. Asupan vitamin E responden pada penelitian ini berada dibawah dan lebih rendah dibandingkan penelitian yang memiliki pengaruh terhadap kadar gula darah.

Asupan vitamin E responden yang rendah dikarenakan beberapa hal. Pertama, adanya underreporting, disebabkan oleh metode wawancara SQ FFQ yang sangat bergantung pada daya ingat didukung oleh faktor usia responden. Kedua, menu makanan yang tidak bervariasi menyebabkan responden tidak memenuhi kebutuhan asupan yang seharusnya dikonsumsi terutama asupan vitamin E. Ketiga, penurunan selera makan dan fungsi sensori yang berkurang. Keempat, pengetahuan responden mengenai fungsi vitamin E terhadap DM masih kurang [21, 26, 32].

Disamping faktor faktor tersebut, asupan lemak memengaruhi penyerapan vitamin E responden. Vitamin E merupakan vitamin yang penyerapannya membutuhkan lemak dan aktivitas asam 
empedu. Asam empedu dihasilkan dari produk akhir metabolisme kolesterol. Asam empedu berfungsi untuk merubah lemak menjadi emulsi lemak dengan cara membentuk komplek asam lemak-asam empedu, sehingga lebih mudah dicerna oleh enzim lipase sebelum diabsorbsi oleh dinding usus [33]. Penelitian yang dilakukan oleh Daud (2014) menyebutkan bahwa vitamin E mampu memberi perlindungan pada lipoprotein terhadap peroksidasi dengan cara mengurangi oksidasi radikal bebas yang merusak lipid [34]. Dalam penelitian ini, asupan lemak responden masih kurang dari kebutuhan yang menyebabkan absorbsi vitamin $\mathrm{E}$ terhambat sehingga peran vitamin $E$ untuk melindungi membran sel dan asam lemak dari oksidasi radikal bebas berkurang. Pertahanan dalam peroksida lipid juga berkurang dan gula darah pada responden tetap meningkat. Pengaturan makan responden pada penelitian ini tidak dapat memenuhi kebutuhan seorang diabetesi. Hal ini disebabkan karena sebagian besar responden adalah golongan lansia yang mengalami penurunan nafsu makan sehingga mempengaruhi asupan makan. Hal ini menyebabkan rendahnya asupan bahan makanan sumber lemak, karbohidrat dan protein. Faktor ekonomi yang tergolong rendah dari responden juga turut mempengaruhi rendahnya asupan zat gizi makro dari responden yang karena rendahnya variasi asupan lauk hewani, nabati, buah dan sayur.

\section{SIMPULAN}

Tidak terdapat hubungan yang signifikan antara asupan vitamin $\mathrm{C}$ dan $\mathrm{E}$ terhadap kadar gula darah pasien rawat jalan DM tipe 2 di Puskesmas Dinoyo dan Janti Kota Malang.

\section{UCAPAN TERIMAKASIH}

Ucapan terimakasih disampaikan kepada Badan Penelitian dan Pengabdian
Kepada Masyarakat (BPPM) Fakultas Kedokteran Universitas Brawijaya atas hibah penelitian DPP/SPP TA. 2016-2017, Dinas Kesehatan Kota Malang, Puskesmas Dinoyo dan Janti, Laboran Lab Prodia Malang, serta anggota tim penelitian DM 2016 (Ganis, Widya, Azmi, Niza).

\section{DAFTAR RUJUKAN}

1. Hapsoro S.E. Uji Penurunan Kadar Glukosa Darah Tablet Effervescent Kombinasi Ekstrak Daun Dewandaru (Eugenia uniflora L.) dan Herba Sambiloto (Andrographis paniculata [Burm.f.] Ness) Pada Tikus yang Dibebani Glukosa. Skripsi. Fakultas Farmasi Universitas Muhammadiyah Surakarta, Surakarta. 2009.

2. RISKESDAS. Riset Kesehatan Dasar. Badan Penelitian dan Pengembangan Kesehatan Kementrian Kesehatan RI. 2013.

3. Gibson dalam Darsana I.N. Korelasi Positif Kadar Asam Urat Serum Tinggi dengan Neuropati Diabetik Perifer pda Penderita DM Tipe 2 di Rumah Sakit Umum Pusat Sanglah Denpasar. Tesis.Program Pascasarjana Universitas Udayana, Denpasar. 2014.

4. Ismail N.A., Okasha S., Dhawan A., Shaker O. Glutathione Peroxidase, Superoxide Dismutase and Catalase Activities in Children with Chronic Hepatitis. Advances in Bioscience and Biotechnology, 2012, 3: 972977.

5. Olanlokun J. Protective Influence of Vitamin E on The Antioxidant Defence System in The Whole Blood and Liver of Normal and AlloxanInduced Diabetic Rats. Indian Journal of Clinical Biochemistry, 2008, 23 (1): 62-66.

6. Chikezie P., Ojiako O., Ogbuji A. Oxidative Stress in Diabetes Mellitus. IJBC, 2015, 9 (3) : 92 - 109. 
7. Idris A.M. Hubungan Pola Makan dengan Kadar Gila Darah pada Pasien Rawat Jalan DM Tipe 2 di Wilayah Kerja Puskesmas Kota Makassar Tahun 2014. Skripsi. Fakultas Kesehatan Masyarakat Universitas Hasanudin, Makassar. 2014.

8. Nurdini A. "Cross Sectional VS Longitudinal": Pilihan Rancangan Waktu Dalam Penelitian Perumahan Pemukiman. Dimensi Teknik Aristektur, 2006, 34(1): 52-58.

9. Allen, L., Benoist,B., Dary,O., Hurrell,R, editor. Guideline on Food Fortification with Micronutrient. France: World Health Organization and Food and Agriculture Organization of the United Nations; 2006. 148-149

10. Perkumpulan Indonesia. 2011. Konsensus Pengendalian dan Pencegahan Diabetes Mellitus Tipe 2 di Indonesia 2011. Jakarta.

11. Salindeho A., Mulyadi, Rottie J. Pengaruh Senam Diabetes Mellitus Terhadap Kadar Gula Darah Penderita Diabetes Melitus Tipe 2 di Sangar Senam Persadia Kabupaten Gorontalo, 2016, 4 (1).

12. Misdarina A, Yesi. Pengetahuan Diabetes Melitus dengan Kadar Gula Darah Pada Pasien DM Tipe 2. EKep, 2012, 2 (2).

13. Ilyas E.I. 2011. Olahraga Bagi Diabetesi dalam: Soegondo, S., Soewondo P., Subekti I., Editor. Penatalaksanaan Diabetes Melitus Terpadu bagi Dokter Maupun Edukator Diabetes. Jakarta: Fakultas Kedokteran Universitas Indonesia

14. Lestari T.S. Hubungan Psiokosoial dan Penyuluhan Gizi dengan Kepatuhan Diet Pasien Diabetes Melitus Tipe 2 Rawat Jalan di RSUP Fatmawati. Skripsi. Universitas Indonesia, Depok. 2012.
15. Syauqi A. Perbedaan Kadar Glukosa Darah Puasa Pasien Diabetes Melitus Berdasarkan Pengetahuan Gizi, Sikap, dan Tindakan di Poli Penyakit Dalam Rumah Sakit Islam Jakarta. Jurnal Gizi Indonesia, 2015, 3 (2) : 60-67.

16. Septyaningrum N., Martini S. Lingkar Perut Mempunyai Hubungan Paling Kuat dengan Kadar Gula Darah. Jurnal Epidemiologi, 2014, 2 (1).

17. Kurnia N., Atoillah M. Hubungan Empat Pilar Pengendalian DM Tipe 2 Dengan Rerata Kadar Gula Darah. Jurnal Berkala Epidemiologi, 2013, 1 (2) : 234-243.

18. Hasibuan S.R. Pengaruh Pemberian Vitamin C Terhadap Efek Analgetika Metampiron pada Marmot. Skripsi. Universitas Sumatera Utara, Medan. 2009.

19. Winahyu P.N. Pengaruh Pra Perlakuan Infusa Kelopak Bunga Rosela terhadap Efek Analgesik Ibuprofen pada Mencit Betina Galur Swiss. Skripsi. Universitas Sanata Dharma, Yogyakarta. 2015.

20. Grober, Uwe. Mikronutrient. Jakarta : EGC. 2009.

21. Utami S., Bintanah S., Isworo $\mathrm{T}$. Hubungan Konsumsi Bahan Makanan Sumber Vitamin C dan Vitamin E dengan Kadar Gula Penderita Diabetes Mellitus Tipe 2 Rawat Jalan di Rumah Sakit Tugurejo Semarang. Jurnal Gizi Unimus, 2015, 4 (1).

22. Traber M., Stevens J.F. Vitamin C and $\mathrm{E}$ : Beneficial Effects from a Mechanistic Perspective. Free Radic Biol Med, 2011, 51 (5) : 1000 - 13.

23. Azrimaidazalia. Asupan Zat Gizi dan Penyakit Diabetes Mellitus. Jurnal Kesehatan Masyarakat, 2011, 6 (1).

24. Wulandari D.N. Hubungan Pola Konsumsi Makanan Sumber Vitamin C terhadap Kadar Gula Darah Puasa Pasien DM tipe 2 di Poliklinik Penyakit Dalam RSU Dr Saiful 
Anwar Malang. Tugas Akhir. Fakultas Kedokteran Universitas Brawijaya, Malang. 2014.

25. Malazy O.T , Nikfar S., Larijani B. Influence of Ascorbic Acid Supplementation on Type 2 Diabetes Mellitus in Observational and Randomizad Controlled Trials;A Systematic Review with Meta Analysis. J Pharm Sci, 2014, 17 (4) 554-582.

26. Ardekani, M.A., Ardekani, A.S. Effect of Vitamin $\mathrm{C}$ on Blood Glucose, Serum Lipids, and Serum Insulin in Type 2 Diabetes Patients. Indian J Med Res, 2007, 126 (5) : 471 -4 .

27. Rafighi Z., Shiva A., Arab S., Yusuf R. Association of Dietary Vitamin C and $\mathrm{E}$ Intake and Antioxidant Enzymes in Type 2 Diabetes Mellitus Patients. Glob J Health, 2013, 5 (3) : $183-7$.

28. Mulyadi C., Fransisca., Pramudya K. Hubungan Antropometri, Aktivitas Fisik, dan Pengetahuan Gizi dengan Asupan Energi dan Komposisi Makronutrien pada Remaja. EJKI, 2013, 1 (2).

29. Yasin Y.K,. Kartasurya, Martha. Pengaruh Kombinasi Vitamin C dan Vitamin E Terhadap Kadar Malondialdehid Plasma Pasien Diabetes Mellitus Tipe 2. Jurnal Gizi Indonesia, 2015, 4 (1) : $1-8$.

30. Nurlita N. 2015. Hubungan Pola Konsumsi Vitamin C terhadap Kadar Glukosa Darah dan Trigliserida pada Pasien Diabetes Melitus Rawat Jalan di RSUD Dr. Moewardi. Skripsi. Universitas Muhammdiyah Surakarta, Surakarta.

31. Jamalan M., Rezazadeh M., Zeinali M., Effect o Ascorbic and Alpha Tocopherol Supplementations on Serum Leptin, Tumor Necrosis Factor Alpha, and Serum Amyloid a Levels Individuals with Type 2 DM. AJP, 2015, 5(6) : 531-539

32. Rafraf M., Bazyun B., Sarabchian M. Impact of Vitamin E Supplementation on Blood Pressure and Hs-CRP in Type 2 Diabetic Patients. Health Promotion Perspectives, 2012, 2 (1) : $72-79$.

33. Fauziah A., Mangisah I., Murningsih W. Pengaruh Penambahan Vitamin E dan Bakteri Asam Laktat Terhadap Kecernaan Lemak dan Bobot Telur Aya, Kedu Hitam. AAJ, 2013,

34. Daud R. Pengaruh Suplementasi Vitamin E terhadap Konsentrasi LDL dan Perubahan Patologis Aorta Tikus Putih Wistar yang diberi Ransum Lemak Tinggi, JMV, 2014, 8(1).

35. Ramadhan N., Marissa N. Karakteristik Penderita Diabetes Mellitus Tipe 2 Berdasarkan Kadar HBA1C di Puskesmas Jayabaru Kota Banda Aceh. SEL, 2015, 2 (2) : 4956.

36. Wandansari K. Hubungan Pola Makan dan Aktivitas Fisik dengan Kejadian Diabetes Mellitus Tipe 2 di RSUD Dr. Moewardi Surakarta. Tugas Akhir. Universitas Muhammadiyah Surakarta, Surakarta. 2013. 